\title{
Krytyka piotrowych rozwiązań synodalnych w łonie Rosyjskiej Cerkwi Prawosławnej w początkach XX wieku
}

\author{
Kamila Pawełczyk-Dura \\ Archiwum Państwowe w Łodzi \\ pawelczyk.kamila@wp.pl
}

\begin{abstract}
K. Pawełczyk-Dura, Criticism of Peter the Great synodical solutions in the Russian Orthodox Church in beginnings of the XX century, Elpis, 20 2018: 187-195.

Abstract: The synodal system, established on Russia by the tsar of Peter the Great, in beginnings of the 20th century was in the deep ideological crisis and the organizational impasse. Social and political tensions, characteristic of the being on the decline autocracy state, were felt also by the Orthodox intelligence, which - carried with the slogans of freedom and self-determination - began to openly criticize the solutions of Peter and demanded the restitution of conciliarity of the Russian Orthodox Church.

Streszczenie: System synodalny, zaszczepiony na gruncie rosyjskim przez cara Piotra Wielkiego, w początkach XX wieku przeżywał głęboki kryzys ideologiczny i impas organizacyjny. Napięcia społeczne i polityczne, charakterystyczne dla chylącego się ku upadkowi państwa samodzierżawnego, odczuwalne były także przez inteligencję prawosławną, która - niesiona hasłami wolności i samostanowienia - przystąpiła do otwartej krytyki rozwiązań piotrowych i wysuwała coraz śmielej żądania restytucji wielowiekowego dziedzictwa soborowości Rosyjskiej Cerkwi Prawosławnej.
\end{abstract}

Keywords: The Russian Orthodox Church, The Most Holy Governing Synod, reforms

Słowa kluczowe: Rosyjska Cerkiew Prawosławna, Świątobliwy Synod Rządzący, reformy

Idea restytucji wielowiekowego dziedzictwa soborowości Rosyjskiej Cerkwi Prawosławnej, równoznaczna $\mathrm{z}$ odrzuceniem funkcjonowania synodalnego syste$\mathrm{mu}$ piotrowego, pojawiła się w rosyjskiej przestrzeni polityczno-społecznej w pierwszym dziesięcioleciu XX wieku za sprawą prawosławnych przedstawicieli kręgu inteligencji. Jej pełnie urzeczywistnienie przyniosły obrady Soboru Lokalnego 1917-1918, nullifikujące Manifest o Kolegium Duchownym cara Piotra I z 25 stycznia 1721 roku, który zniósł instytucję patriarchatu i godność pierwszego hierarchy, powołując $\mathrm{w}$ ich miejsce organ zarządu kolegialnego - Świątobliwy Synod Rządzący ${ }^{1}$, kierowany przez carskiego urzędnika $\mathrm{w}$ randze oberprokuratora.

Mechanizm funkcjonowania samodzierżawnego me-

\footnotetext{
Podczas obrad Soboru Lokalnego, podjęto prace nad reformą tytulatur wewnątrzcerkiewnych. Wraz z powrotem do instytucji patriarchatu w Rosyjskiej Cerkwi Prawosławnej tytułem „świątobliwego” obdarzono nowego patriarchę (Świątobliwy Patriarcha Moskiewski i Wszechrosji). To samo miano przysługiwało od 1721 roku Synodowi (Świątobliwy Synod Rządzący). Na mocy postanowienia soborowego z 31 stycznia 1918 roku przyjęto zmiany w oficjalnym nazewnictwie. Przymiotnik ,świątobliwy" został zachowany przy tytulaturze patriarchy. Świątobliwy Synod Rządzący przemianowano na Święty Synod. Nazwa ta będzie stosowana w niniejszej pracy na określenie zgromadzenia funkcjonującego od 1917 roku. Zob.: М. А. Бабкин, Свяменство и Царство. Россия начало ХХ века - 1918 г. Исследования и материалы, Москва 2011, с. 495-496; С. Л. Фирсов, Русская Церковь накануне перемен (конеи 1890-х 1918 г2), Москва 2002, с. 126-146; Д. В. Каннингем, С надеждой на собор. Русское религиозное пробуждение начала века, Лондон 1990, c. $65-68$.
}

chanizmu synodalnego, ustawodawczo spychającego Kościół prawosławny w Rosji do roli instytucji życia publicznego, podporządkowanej władcy i kontrolowanej przez jego aparat urzędniczy, już w XVIII wieku budził kontrowersje. Odwołując się do tradycji Kościołów Wschodu wykazywano niekanoniczność przyjętych rozwiązań i brzemienność odrzucenia ducha soborowości. Pomimo oporu części świeckich i duchownych członków wspólnoty wyraźne symptomy dekompozycji systemu piotrowego ujawniły się na fali zachodzących w Imperium Romanowów przemian społecznych, warunkujących rozwój ruchu reformatorskiego. Począwszy od końca XIX wieku na łamach poczytnych pism religijnych i świeckich otwarcie podnoszono potrzebę głębokich, systemowych reform wewnątrzpaństwowych, w tym koniecznych przeobrażeń cerkiewnych.

Pod wpływem rosnącego nacisku społecznego 12 grudnia 1904 roku na obszarze Imperium Rosyjskiego opublikowano ukaz „O udoskonaleniu porządku publicznego”, a wraz za nim rozporządzenie Rady Ministrów w sprawie natychmiastowego zniesienia środków sankcyjnych przyjętych przez administrację państwową w odniesieniu do mienia przynależnego nieprawosławnym związkom religijnym. Projekt zakładał rewizję prawnego stanowiska carskiego aparatu władzy, głównie w stosunku do staroobrzędowców, głosząc nośne społecznie hasła szkodliwości ingerencji administracji w sprawy wiary i ferując przekonanie o destruktywności aktów przemocy wobec 
niewierzących ${ }^{2}$. Konsekwencją zmian było nadanie każdemu związkowi religijnemu samodzielności, niezależności w dziedzinie wewnętrznego i zewnętrznego stanowienia. Grudniowa ustawa nie dotyczyła, jak podkreślono powyżej, pozostającego formalnie pod „opieką" ober prokuratora Kościoła prawosławnego, skrępowanego przez aparat władzy węzłami administracyjnymi i ideologicznymi ${ }^{3}$.

W obronie Rosyjskiej Cerkwi Prawosławnej wystąpił metropolita petersburski i ładoski Antonij (Wadkowskij) ${ }^{4}$. Swoje stanowisko $\mathrm{w}$ imieniu podporządkowanego mu duchowieństwa stolicy Imperium przedstawił pod rozpatrzenie cara Mikołaja II w formie notatki $W$ sprawie oczekiwanych zmian $w$ zarządzie cerkiewnym ${ }^{5}$. Treść dokumentu została oparta na tezie wprowadzenia niezbędnych dla dalszego rozwoju żywego organizmu wspólnotowego reform cerkiewnych, nawiązujących legislacyjnie do zapisów prawa z 12 grudnia. „Ogłosić swobodę wyznania, oznacza rozwiązać wszystkim ręce, a działaczy cerkiewnych pozostawić związanymi" - twierdził hierarcha ${ }^{6}$. Podkreślał, że każda konfesja, nie wyłączając stanowiących podporę władzy państwowej prawosławnych, winna nieskrępowanie, w zgodzie z kanonami i tradycją, kształtować własne struktury i zarząd ${ }^{7}$. Nadanie autonomii Kościołowi prawosławnemu w Rosji, przynieść miało - w opinii metropolity - korzyści tronowi i ołtarzowi. Podkreślał dobitnie, że Cerkiew stanowi od wieków trwały element rządów monarchicznych, a władza świecka winna dbać o jej stabilny ustrój wewnętrzny. Żywe ciało Kościoła, aby nieustannie pracować na rzecz państwa, potrzebowało przeobrażeń

\footnotetext{
Staroobrzędowcy, starowierzy, starowiercy, raskolnicy, lipowanie (ros. старообрядчество) - odłam prawosławia, powstały w Rosji w II połowie XVII wieku. Przyczyną schizmy stały się reformy patriarchy Nikona, zmierzające do zmian w obrządku prawosławnym (m. in. czynienie znaku krzyża trzema palcami oraz poprawiona pisownia imienia Jezus). Staroobrzędowcy postrzegali te zmiany jako herezję i dołaczyli sie od Cerkwi patriarszej, za co zostali potepieni. Od tego czasu, aż do 1904 roku uznawani byli za schizmatyków i sektantów, odrzucających autorytet oficjalnego Kościoła prawosławnego. Zob. С. Зеньковский, Русское старообрядчество: Духовнье движения XVII века, Москва 1995, с. 25-49; В. Миловидов, Старообрядчество в прошлом и настоящем, Москва 1969, с. 3-4. W języku polskim ukazało się kilkanaście prac poświęconych staroobrzędowcom, wśród których wymienić należy: E. Przybył, $W$ cieniu Antychrysta: idee staroobrzędowców w XVII w., Kraków 1999; Żywot protopopa Awwakuma przez niego samego nakreślony i wybór innych pism, red. W. Jakubowski, Wrocław-Gdańsk 1972; U. Cierniak, Literacki wymiar kultury religijnej staroobrzędowców, Częstochowa 1997; H. Kowalska, Konserwatyzm staroobrzędowców rosyjskich. Próba obrony tożsamości i ciagłości kulturowej, [w:] Miasto i kultura ludowa w dziejach Białorusi, Litwy, Polski i Ukrainy, red. J. Wyrozumski, Kraków 1966, s. 257-266.

М. Б. Данилушкин, Т. К. Никольская, М. В. Шкаровский, В. П. Дмитриев, Б. П. Кутузов, История Русской Православной Церкви. От восстановления патриариества до наших дней 1917-1970 г2., Санкт-Петербург 1997, т. 1, с. 64; Георгий (Флоровский), Пути русского богословия, Париж 1983, с. 476.

4 A. A. Bogolepov, Church Reforms in Russia 1905-1918, Bridgeport 1966, p. 12-14; И. Басин, Пастырь на рубеже эпох. K 150-летию со дня рождения митрополита Антония (Вадковского), „Православная община", 1996, № 3, с. 82-83.

С. Ю. Витте, Воспоминания, Москва 1960, т. 1, с. 319-342; Российский государственный исторический архив, Яикевич Виктор Иванович (1861-1924), Директор Канщелярии обер-прокурора Синода, ф. 1579, оп. 1, д. 36, л. 1об-2.

6 Георгий (Флоровский), op. cit.,c. 476. O ile nie zaznaczono inaczej, cytaty obcojęzyczne przytaczam we własnym tłumaczeniu.

Д. В. Поспеловский, Русская Православная Церковь в ХХ в., Москва 1995 , с. 25
}

wewnętrznych, adekwatnych do własnych potrzeb, a nie woli monarchy ${ }^{8}$.

Projektowane przez metropolitę reformy postulowały decentralizację administracji cerkiewnej, ożywienie działalności parafii jako najniższej i najważniejszej jednostki cerkiewnej administracji terenowej, udział czynnika świeckiego w zarządzie cerkiewnym oraz tworzenie instytucji państwowych o funkcjach kreacyjnych, których członkami mogliby zostać duchowni ${ }^{9}$. Aby odrodzenie stało się rzeczywistością, twierdził duchowny, należało „zwołać specjalne posiedzenie złożone z przedstawicieli hierarchii cerkiewnej, z udziałem osób ze stanu duchownego i świeckiego celem analizy istniejących norm administracyjnych i opracowaniem koniecznych zmian" - inaczej rzecz ujmując soboru, który opracowałby i wprowadził w życie powyższe postulaty ${ }^{10}$.

Metropolita Antonij przedstawił swoje oficjalne stanowisko na plenum Komitetu Ministrów Imperium Rosyjskiego ${ }^{11}$. Jego przewodniczący Siergiej Witte z zainteresowaniem odniósł się do idei reformatorskiej. W notatce O współczesnym położeniu Cerkwi prawosławnej ${ }^{12}$ przedstawił w lutym 1905 roku autorski projekt przekształceń wewnątrzcerkiewnych ${ }^{13}$. Funkcjonujący od czasów piotrowych model synodalny przyczynił się, według polityka, do całkowitego paraliżu administracyjnego Cerkwi, upadku znaczenia parafii, degradacji znaczenia szkoły religijnej i rozprężenia dyscypliny cerkiewnej ${ }^{14}$. Witte akcentował, iż system zależności Kościoła od państwa był nie tylko niekanoniczny, ale także niebezpieczny dla samego państwa, pozbawionego duchowego i moralnego wsparcia będącej na usługach aparatu kontroli i przymusu religii:

8 С. С. Бычков, Русская Церковь и императорская власть. Очерки по истории Православной Российской цееркви 1900-1917 г2., Москва 1998, т. 1, с. 79; Николай (Балашов), Всероссийский Церковный Собор 1917-1918 годов. Некоторые детали предыстории, „Церковь и время", 2000, № 3 (12), с. 155-178.

Антоний (Вадковский), Вопросы о желательных преобразованиях в постановке у нас православной цеекки, „Новое время”, 1905, № 10, c. $133-136$.

10 Ibidem, с. 136; С. Л. Фирсов, Митрополит Санкт-Петербургский и Ладожский Антоний (Вадковский) и проблема реформы Высшего Церковного управления в годы Первой российской революиии, [в:] Ежегодная богословская конференция Православного СвятоТихоновского Богословского Института. Материаль, ред. В. Н. Воробьёв, Москва 1996, с. 337-338.

11 W literaturze przedmiotu podkreśla się, że duchowny nie zaprezentował swoich poglądów na posiedzeniach Swiątobliwego Synodu - organu zajmującego się właśnie problemami Kościoła prawosławnego w Rosji, lecz właśnie podczas posiedzenia Komitetu Ministrów. Wytłumaczenia tego paradoksu szukano w postawie kierowników tych dwóch ciał: oberprokuratora Konstantina Pobiedonoscewa i przewodniczącego Siergieja Wittego. Георгий (Ореханов), Витте contra Победоносиев: дискуссия о иерковной реформе весной и летом 1905 года, „Журнал Московской Патриархии", 2001, № 11, с. 48-70.

2 S. Witte pisał w swoich wspomnieniach: „Notatke te napisał jeden z moich pomocników”. Owym ,pomocnikiem” był najprawdopodobniej biskup Arsenij (Stadnickij). Por.: С. Ю. Витте, Воспоминания, Москва 1960 , т. 2 , с. 364

Император Николай и Поместный Собор русской православной иеркви. Два письма (публ. Г. Ореханова), „Богословский сборник Православного Свято-Тихоновского богословского института”, 1999 , № 2, с. 69, С. Л. Фирсов, Русская Церковь накануне перемен (конеи 1890-x - 1918 г2)..., с. 467; Георгий (Флоровский), op. cit., с. 476-477. 14 Иакинф (Дестивель), Поместный Собор Российской Православной Церкви 1917-1918 г2. и приниип соборности, Москва 2008, с. 58-59. 
„Ponad dwieście lat nie słuchaliśmy głosu świętej Cerkwi. Czy nie nadeszła w końcu pora go wysłuchać; czy nie nadszedł czas dowiedzieć się, co ona ma do powiedzenia? [...] W obliczu społecznej destabilizacji nie można dłużej zwlekać. Religia jest podporą ducha narodu [...] Tylko z jej pomocą wyjdziemy obronną ręką z niebezpieczeństw tych trudnych czasów. Nie możemy obezwładnić rozwoju i przejawów swobody Kościoła prawosławnego pragnieniem zamknięcia jej w ramy suchych biurokratycznych praw, jak to się czyni obecnie" ${ }^{\text {15. }}$.

W poglądach Wittego pojawia się dążenie do odnowienia apostolskich źródeł funkcjonowania wspólnoty, kryjących się w zasadzie soborowości. Powrót do zasady regularnego zwoływania soborów jako nadrzędnej formy zarządu Kościołem prawosławnym, zdaniem polityka, wyzwoliłoby duchowieństwo spod jarzma ułomnej w swej naturze kolegialności. Epoka synodalna, twierdził, doprowadziła do obumarcia żywego i rozwijającego się organizmu cerkiewnego. Miejsce organicznej relacji wspólnotowej zajął aparat kancelaryjny właściwy państwu biurokratycznemu ${ }^{16}$. Cerkiew potrzebowała głębokich przemian strukturalnych, przystosowujących ją do pełnienia ważnych społecznie funkcji. „Religijne odrodzenie jest początkiem odrodzenia społecznego; rozwija się i umacnia tam, gdzie społeczeństwu daje się swobodę" - podsumowywa ${ }^{17}$.

Analizowany dokument, podobnie jak projekt metropolity Antonija, nie odrzucał sojuszu Cerkwi z monarchią, nierozerwalnego związku tronu i ołtarza. Prawosławie stanowiło, w zamyśle autorów tych dwóch tekstów, odwieczny i podstawowy substrat kultury rosyjskiej, stały element życia społecznego i politycznego. Nie uchylając się od tradycyjnego modelu współżycia w przestrzeni publicznej władzy świeckiej i Kościoła, sugerowano rewizję stanowiska państwa wobec prawosławnych. Przyjęte przez ministra i duchownego rozwiązania wykazywały zasadniczą inkongruencję w zakresie oczekiwanych rezultatów. Antonij, nawołując do przeprowadzenia reform wewnątrzcerkiewnych, postrzegał Cerkiew jako instytucję silną i niezależną od carskiego aparatu władzy, rządzącą się własnymi prawami i zasadami. Witte natomiast, wykorzystując autorytet Kościoła prawosławnego, próbował włączyć wspólnotę w sprawy polityczne i wykorzystując jej dominującą pozycję wzmocnić władzę państwową ${ }^{18}$.

Do idei reformatorskiej jako ogólnej tendencji projektowanych przeobrażeń wewnątrzcerkiewnych krytycznie odniósł się oberprokurator Świątobliwego Synodu Rzą-

\footnotetext{
С. Ю. Витте, О современном положении православной Церкви, „Слово”, 1905, № 108, с. 75.

16 Савва (Тутунов), У истоков Предсоборного присутствия 1906 года. Церковно-общественные дискуссии и отзывы архиереев, „Московские Епархиальные Ведомости”, 2011, № 7/8, с. 141-144; С. Л. Фирсов, Русская Церковь накануне перемен (конеи 1890-х 1918 г2)..., с. $151-152$.

17 С. Ю. Витте, О современном положении православной Церкви..., c. 92.

18 Д. А. Головушкин, Феномен обновленчества в русском православии первой половины ХХ века, Санкт-Петербург 2009, с. 41-58.
}

dzącego ${ }^{19}$. Konstantin Pobiedonoscew, kierujący przez blisko dwadzieścia pięć lat pracami zgromadzenia, kreował politykę cerkiewną, podporządkowując ją ideałowi nienaruszalności życia kościelnego i prymatowi wartości tradycyjnych. Jego dążenie do odbudowy w społeczeństwie dyscypliny, pokory oraz żarliwości religijnej pozostawało z opozycji do lutowych deklaracji. 2 marca 1905 roku jeden z najwybitniejszych ideologów rosyjskiego konserwatyzmu, zwolennik samowładztwa i władzy teokratycznej, w specjalnym liście kierowanym do imperatora Mikołaja II wyraźnie zaznaczał, iż wprowadzenie jakichkolwiek zmian w systemie zarządu Cerkwią doprowadzi do osłabienia pozycji Świątobliwego Synodu i załamania systemu piotrowego. W odrzuceniu zasady kolegialności upatrywał niebezpieczeństwo wskrzeszenia samowładztwa cerkiewnego, zachwiania równowagi między władzą kościelną a władzą państwową. W zaistniałych warunkach społeczno-politycznych należało, w jego opinii, ze szczególną emfazą pielęgnować model synodalny, pozwalający duchowieństwu zajmować się sprawami swoich wiernych, krzewieniem prawosławia i wspomagający ich dzieło od strony administracyjnej przez urzędników carskich. Cerkiew, zdaniem Pobiedonoscewa, nie była organizmem zdolnym do przejęcia obowiązków władzy naczelnej i prawidłowego kształtowania swej struktury. Kontrola państwa, prowadzona na rzecz dobra całej wspólnoty, była jego mniemaniu koniecznością ${ }^{20}$.

Alternatywą wobec projektów zwołania soboru lokalnego w jego ogólnorosyjskim wymiarze stało się proponowane przez oberprokuratora utworzenie koncylium arcybiskupiego, obradującego pod przewodnictwem jednego z metropolitów. Do jego zadań należałoby usprawnienie systemu synodalnego, wybór pierwszego hierarchy rosyjskiej Cerkwi prawosławnej oraz opracowanie szerokiego katalogu zagadnień odnośnie do zmian, jakie wprowadzić miałby Świątobliwy Synod ${ }^{21}$. Połowiczność przyjętego

\footnotetext{
19 Переписка С. Ю. Витте и К. П. Победоносиева, „Красный архив”, 1928, т. 5, № 30, с. 108-114; В. Л. Шленов, , Безумная иерковная смута" и расхождения в оченке синодального строя и реформ Пе mpa I, „Просветитель”, 1994, № 1, с. 150-153; С. Л. Фирсов, Человек во времени: иттихи к портрету Константина Петровича Победоносиева, [в:] К. П. Победоносиев: pro et contra. Личность, общественно-политическая деятельность и мировоззрение Константина Победоносиева в оценке русских мыслителей и исследователей. Антология, ред. Д. К. Бурлака, Санкт-Петербург 1996, с. 6-27. O postawie Pobiedonoscewa zob. też: P. Stawiński, Walka prawosławia ze sztundyzmem w świetle soboru kijowskiego z roku 1884, [w:] Prawostawie, red. J. Drabina, Kraków 1996, s. 89-94.

20 К. П. Победоносцев, Московский сборник. Церковь и государство, Москва 1896, с. 1-6; Письма Победоносиева к Александру III, Москва 1926, т. 2, с. 134-156; Из писем К. П. Победоносиева к Николаю II (1898-1905), публ. М. Н. Курова, „Религии мира. История и современность”, 1983, № 37, с. 163-194; Из черновых бумаг К. П. Победоносиева, „Красный архив”, 1926, т. 5, № 18, с. 203-207; Иакинф (Дестивель), оp. cit., с. 60-62; Современники о патриархе Tuхоне, сост. М. Е. Губонин, Москва 2007, т. 2, с. 281-282. Zob. też: U. Cierniak, Konstanty Pobiedonoscew - niewystuchany prorok czy zhy geniusz Rosji, [w:] Panorama myśli kontrrewolucyjnej, red. J. Goćkowski, J. Bartyzel, M. Bohun, A. Woźniak, Pułtusk 2007, s. 205-223.

${ }_{21}$ И. В. Преображенский, Сборник статей духовной и светской периодической печати по вопросу о реформе, Санкт-Петербург 1905, с. 484-488; А. Ю. Полунов, К. П. Победоносиев, Святейший Синод и архиереи, „Вестник Московского университета. Серия 8: История”, 1999, № 4, с. 22-23.
} 
rozwiązania była wyrazem konserwatyzmu Pobiedonoscewa, który nie chcąc wprowadzać diametralnych zmian $\mathrm{w}$ istniejących strukturach cerkiewnych $-\mathrm{z}$ jednej, a zarazem uspokoić opinię społeczną, czekającą i domagającą się coraz głośniej reform - z drugiej strony, wypracował „bezpieczny”, w jego odczuciu, model przeobrażeń wewnątrzcerkiewnych ${ }^{22}$.

13 marca 1905 roku Pobiedonoscew przedłożył carowi propozycję przeniesienia sprawy reform wewnętrznych wspólnoty prawosławnej z gabinetu przewodniczącego Komitetu Ministrów pod jurysdykcję Świątobliwego Synodu, prośbę swoją motywując dobrem państwa samodzierżawnego, Cerkwi rosyjskiej i jej wiernych. Na 17 marca, zgodnie z decyzją Mikołaja II, zostało wyznaczone ekstraordynaryjne posiedzenie synodalne z udziałem hierarchów i oberprokuratora ${ }^{23}$.

W dniu zwołania wspomnianego konsylium synodalnego ukazał się artykuł prasowy $O$ konieczności zmian w rosyjskim zarzadzie cerkiewnym, bardziej znany jako Pierwsza notatka trzydziestu dwóch duchownych ${ }^{24}$. Nieformalna grupa trzydziestu dwóch zrzeszała aktywnych członków wspólnoty prawosławnej, wywodzących się najprawdopodobniej z liberalnego środowiska petersburskiej inteligencji. Lapidarność tekstu nie pozwala jednak w pełni ustalić tożsamości osób wchodzących w skład tej formacji, jak też podłoża współpracy w ramach związku. Rzutuje to na trudności we wskazaniu pomysłodawcy powstania artykułu publicystycznego W literaturze przedmiotu wskazuje się, że udział w tworzeniu tekstu mieli kapłan Grigorij Pietrow, profesor Michaił Gorczakow, archimandryta Michaił (Siemienow) oraz rosyjski publicysta, teolog i historyk Nikołaj Aksakow. Wśród czołowych inicjatorów przedsięwzięcia wymienia się ponadto metropolitę petersburskiego Antonija ${ }^{25}$.

Pierwsza notatka trzydziestu dwóch duchownych została opublikowana 17 marca 1905 roku na łamach czasopisma Cerkownyj Wiestnik. We wstępie głoszono:

„Obecne położenie duchowieństwa stolicy, a tym samym pasterzy całej Rosji, jest niezwykle trudne. Ze wszystkich stron słychać żądania, prośby, żale

\footnotetext{
Современники о патриархе Тихоне..,, с. 282; В. М. Лавров, В. В. Лобанов, И. В. Лобанова, А. В. Мазырин, Иерархия Русской Православной иеркви, патриаршество и государство в револючионную эпоху, Москва 2008, с. 61.

23 С. Л. Фирсов, Русская Церковь накануне перемен (конеи 1890-х 1918 г2.)..., с. $152-162$.

24 Георгий(Ореханов),Генезисрусскогоиерковногореформаторства (1905-1906 22.), „Богословский сборник Православного СвятоТихоновского богословского института", 1999, № 4, с. 295-297; М. А. Бабкин, op. cit., с. 82-83.

25 Георгий(Ореханов), Церковный соборичерковно-реформаторское движение, „Журнал Московской Патриархии”, 2000, № 12, с. 72-73; С. Л. Фирсов, Русская Церковь накануне перемен (конеи 1890-х - 1918 г2.)..., с. 318-321; idem, „Записка 32-х священников” как источник по истории Православной Россйской Церкви, „Русское прошлое”, 1996, №7, с. 389-400; С. С. Бычков, op. cit., с. 84-86; Владислав (Цыпин), История Русской Церкви 1917-1997, Москва 1997, с. 9-10; M. Maszkiewicz, Mistyka i rewolucja. Aleksander Wwiedeński i jego koncepcja roli cerkwi w państwie komunistycznym, Kraków 1995, s. 14; P. Stawiński, Sekty, schizmy i herezje w Rosji. Stownik, Kraków 2000, s. 209-210
}

będące głosem cierpienia duszy: wymaga się do nas jasnej odpowiedzi na pytania o kierunek rozwoju życia społecznego. [...] U wielu w tym czasie smutku i strachu pojawia się powątpiewanie - czy podążać drogą Cerkwi czy też odłączyć się od niej”26.

Odbudowa autorytetu religijnego w społeczeństwie wymagała, jak podkreślano $\mathrm{w}$ dalszej części tekstu podjęcia środków radykalnych, gruntownych i stanowczych. Połowiczne zmiany, mające na celu chwilowe uspokojenie nastrojów społecznych, stanowiłyby jedynie mylną, nieprawdziwą i niebezpieczną w dalekosiężnych konsekwencjach odpowiedź państwa na autentyczne potrzeby Kościoła i jego wiernych. Odnowa życia religijnego w jego najpełniejszej formie nie mogła być podjęta, według autora lub autorów tekstu prasowego, odgórnie, na zasadzie ukazów. Winna wypływać z przemyśleń hierarchów i działaczy świeckich, którzy we wspólnym dziele soborowym wypracowaliby model zarządu wspólnoty:

„Nie mamy wątpliwości co do jednego - w tej godzinie próby potrzeba nam pełnej jedności. Nic nie zmienią żadne ukazy kancelaryjne, cyrkularze i posłania. [...] Należy wysłuchać głosu całej rosyjskiej Cerkwi, głosu świadomości religijnej, przed którego autorytetem ulegną i pasterze, i ich pastwa. Nie słyszeliśmy go prawie dwieście lat. Dwieście lat nie były zwoływane w Cerkwi rosyjskiej sobory, choć potrzeba ta zrodziła się już dawno temu"27.

Na przyszły sobór nakładano szereg zadań, artykułując w szczególności pomysły ustanowienia niezależności wobec organów władzy państwowej i wynikające stąd wprowadzenie zasady samostanowienia Kościoła oraz uznania soborowości za naczelną formę zarządu. Idee te, oszczędnie wyłożone w Notatce trzydziestu dwóch, rozwinięto $\mathrm{w}$ liście, swoistym posłaniu ${ }^{28}$. Zarysowano $\mathrm{w}$ nim projekt odnowy religijnej, wprowadzanej soborowo przez pryzmat zachowania kolegialności na każdym szczeblu cerkiewnej administracji wewnętrznej, przywiązania duszpasterza do swoich wiernych oraz nadania każdej jednostce zarządu większej autonomii. Przedstawiony model dualizmu i demokracji miał stać się gwarantem stopniowej, nierewolucyjnej przebudowy struktur kościelnych. Reformy, realizowane stopniowo w ciągu kilku lat, powinny umożliwić symbiozę oraz stworzyć solidne podwaliny przeobrażeń stosunków państwo - Kościół prawosławny ${ }^{29}$.

Tak zwana Druga notatka trzydziestu dwóch duchownych, opublikowana pod tytułem prasowym $O$ sktadzie soboru, stanowiła kontynuację wyłożonego wyżej programu ideowego rosyjskiej inteligencji. Proponowano

\footnotetext{
О необходимости перемен в русском иерковном управлении, „Церковный вестник”, 1905, № 11, с. 321.

27 Ibidem, c. 323.

28 О преобразовании иерковного управления в России на соборном начале, „Прибавления к Церковным ведомостям”, 1905, № 45, c. 1900

29 О необходимости перемен в русском церковном управлении..., c. 321-325.
} 
trójstopniową, w pełni demokratyczną ordynację wyborczą, w której przedstawiciele niższego duchowieństwa i laikatu stanowiliby przeciwwagę dla dotychczasowego kreatora polityki cerkiewnej - episkopatu ${ }^{30}$. Krytykowano nierówności między biskupami, zabiegającymi o awanse w hierarchii, w szczególności o przeniesienie z mniejszych diecezji do ważniejszych ośrodków. Odrzucano proceder częstych zmian biskupich w diecezjach jako wypaczających misję chrześcijańskiej posługi kapłańskiej. Według autora lub autorów tekstu taka polityka kadrowa sprowadzała biskupów, arcykapłanów do kategorii zwykłych urzędników państwowych - zmieniających miejsce pracy, pnących się w strukturze Kościoła, niezwiązanych ze swoimi wiernymi oraz nagradzanych za zasługi orderami i nagrodami carskimi ${ }^{31}$.

17 marca odbyło się planowane posiedzenie Świątobliwego Synodu. W czasie trwania koncylium odczytano treść ukazu carskiego. Monarcha informował zebranych o swoim poparciu wobec idei reformatorskiej. Kierunek projektowanych przeobrażeń wewnątrzcerkiewnych mieli jednakże kształtować członkowie zgromadzenia synodalnego. Odpowiedzią duchownych na orzeczenie Mikołaja II było posłanie wyrażające głęboką wdzięczność za przychylność wobec ich inicjatywy oraz dające obietnicę posłusznego i pokornego wypełnienia każdej woli imperatora $^{32}$.

W pospiesznej odpowiedzi na propozycję samowładcy, a głównie w obawie przed działaniami zwolennika dotychczasowego systemu Pobiedonoscewa, sporządzano wstępny projekt reform. W ciągu zaledwie pięciu dni zatwierdzono ogólny zarys programu obrad przyszłego zebrania. Proponowano powołanie na tron cerkiewny wszechrosyjskiego patriarchy, który wespół ze Świątobliwym Synodem posiadałby pełnię władzy wykonawczej i ustawodawczej w Kościele prawosławnym, zakreślono plan zmian w administracji szkół duchownych oraz projekt reform koniecznych do przeprowadzenia na poziomie parafii, postulowano udział duchowieństwa $\mathrm{w}$ obradach Rady Państwa i Komitetu Ministrów ${ }^{33}$. Projekt zaprezentowano na posiedzeniu kolegium arcybiskupiego już 22 marca, korzystając ze zdrowotnej niedyspozycji siedemdziesięcioletniego oberprokuratora, zastępowanego przez bliskiego współpracownika i przyszłego „opiekuna” Cerkwi - Władimira Sablera. Ten, wyrażając oficjalnie swoją przychylność wobec przedłożonej mu pod rozpatrzenie idei reformatorskiej, odniósł się do planów duchowieństwa pozytywnie. „Teraz jest jasne, że ten człowiek mnie okłamywał i kopał pode mną dołki” - komentował

\footnotetext{
30 И. Заиканов, Предисловие к публикации, „Православная община”, 1998, № 5, с. 79-88.

31 Д. В. Поспеловский, op. cit., с. 27-28; idem, Обновленчество переосмысление течения в свете архивных документов, „Вестник русского христианского движения”, 1993, № 168, с. 197-227; С. Л. Фирсов, Русская Церковь накануне перемен (конец 1890-х - 1918 г2)..., с. 321-322; Владислав (Цыпин), op. cit., с. 9-10.

32 С. Л. Фирсов, Русская Церковь накануне перемен (конеи 1890-х 1918 22)..., с. 164

33 Георгий (Ореханов), На пути к собору. Церковные реформы и первая русская революция, Москва 2002, с. 69-70.
}

Pobiedonoscew postępowanie swojego następcy w latach $1911-1915^{34}$.

Stanowisko Pobiedonoscewa na projekt wyższego duchowieństwa zostało wyrażone w raporcie z 25 marca, przygotowanym na polecenie cara. Konserwatywny oberprokurator ostrzegał władcę, że zgoda na powołanie soboru biskupiego doprowadzi do głębokich podziałów i katastrofalnych rozłamów w łonie Cerkwi rosyjskiej. Podkreślał, iż niższe duchowieństwo cerkiewne, w większości stanowiące kler parafialny, jest zdecydowanym i aktywnym przeciwnikiem jedynowładztwa hierarchów. Działalność członków Świątobliwego Synodu, dążących do reform odpowiadających interesowi ich grupy i lekceważących głos pozostałych członków wspólnoty, doprowadzi - w jego wyobrażeniu - do eskalacji niezadowolenia ogólnospolecznego. Nastroje te wykorzystywali na ulicach, zdaniem Pobiedonoscewa, rosyjscy rewolucjoniści ${ }^{35}$. Prosił zatem pokornie następnym liście z 30 marca:

„Jest koniecznym, aby ostateczne słowo cara położyło kres tej trudnej sytuacji, przyniosło uspokojenie i wprowadziło duchowieństwo na odpowiednie ścieżki. W tych ciężkich czasach, jakie przeżywa Rosja, potrzeba nam równowagi i spokoju. Wszyscy przeczuwają, że zwołanie jakiegokolwiek soboru w tej chwili byłoby krokiem nieprzemyślanym i przyczyniłoby się do powstania niepotrzebnych rozłamów" ${ }^{36}$.

Ogląd rzeczywistości, zaprezentowany przez oberprokuratora, odwoływał się aktualnej, napiętej sytuacji społeczno-politycznej Rosji carskiej. Imperium Romanowów było na początkach wieku XX państwem zapóźnionym pod względem ustrojowym i ekonomicznym, podtrzymującym system monarchii absolutnej za pomocą niewydolnego i skorumpowanego aparatu biurokratycznego. Zacofanie gospodarcze pogłębiało jedynie kryzys polityczny i potęgowało frustracje społeczeństwa. Blask Imperium przywrócić miała wojna na Japonią, rozpoczęta w 1904 roku. Konflikt, nieprzynoszący zwycięstwa, obciążył jedynie niewydolną gospodarkę kraju oraz spotęgował niezadowolenie mieszkańców stolicy. Odwrotnie proporcjonalny do zarobków wzrost cen i rosnące bezrobocie stały się przyczyną demonstracji robotników fabrycznych w Petersburgu. Na ulice stolicy pojawiło się blisko dwustutysięczna rzesza ludzi, kierowana przez prawosławnego duchownego - Gieorgija Gapona ${ }^{37}$.

\footnotetext{
34 Cyt. za: idem, Buтmе contra Победоносиев: дискуссия о иерковной реформе весной и летом 1905 года..., с. 48.

35 М. А. Бабкин, op. cit., с. 71; В. И. Яцкевич, К истории созыва Поместного Собора Всероссийской Православной Церкви, „Церковь и время", 2000, № 3, с. 133-145.

36 Cyt. za: Современники о патриархе Тихоне.., с. 282.

L. Bazylow, Ostatnie lata Rosji carskiej. Rzady Stolypina, Warszawa 2008, s. 34-52, 135-166; R. Pipes, Rewolucja rosyjska, przel. T. Szafar, Warszawa 2006, c. 3-54; J. Sobczak, Mikołaj II - ostatni car Rosji, Warszawa 2009, s. 311-318; B. Williams, Lenin, przeł. A. Tuszyńska, Wrocław 2002, s. 48-55; J. Pajewski, Historia powszechna 1871-1918, Warszawa 1998, s. 247; D. Marples, Historia ZSRR od rewolucji do rozpadu, przeł. I. Scharoch, Wrocław 2006, s. 28-31; M. Heller, Historia Imperium Rosyjskiego, przeł. E. Melech, T. Kaczmarek, Warszawa 2002, s. 681-692.
} 
Syn bogatego chłopa z Połtawszczyzny, wychowanek tamtejszego seminarium duchownego i absolwent Petersburskiej Akademii Duchownej od kilku lat był silnie związany z lokalnym środowiskiem robotniczym. Troszcząc się o interesy tej najsilniej eksploatowanej grupy społecznej kapłan, a jednocześnie energiczny działacz społeczny i religijny założył Stowarzyszenie Rosyjskich Robotników Fabrycznych Miasta Petersburga, zajmujące się obroną praw oraz podnoszeniem moralnego i religijnego poziomu warstw najniższych ${ }^{38}$. Aktywność duchownego kierowała się ponadto na uświadomienie robotnikom stolicy własnej siły i potencjału w nich drzemiącego. W literaturze przedmiotu podkreśla się, iż rezultatem jego działalności stały się wydarzenia „krwawej niedzieli” 22 stycznia 1905 roku - strajku robotniczego w Petersburgu, brutalnie stłumionego przez carską policję i wojsko ${ }^{39}$.

Styczniowe zajście wywołało falę demonstracji, intensyfikowaną postępowaniem cara wydającego rozkaz bezwzględnego uspokojenia wystąpień. Wraz z rozprzestrzeniającymi się pogłoskami o bilansie starć $\mathrm{z}$ carską policją, bezwzględnie atakującą bezbronnych demonstrantów, społecznej dezaprobacie i piętnowaniu poddano postawę pozostałej części duchowieństwa, odwracającej się od Gapona. 27 stycznia Świątobliwy Synod opublikował posłanie $W$ sprawie buntu robotniczego. W wyższe duchowieństwo odniosło się do wydarzeń sprzed pięciu dni tymi słowy:

„Widząc nieporządek panujący wśród narodu rosyjskiego, w imieniu świętej matki - Cerkwi prosimy jej dzieci: «Boga się bójcie, króla czcijcie» (1 P 1,17) i pamiętajcie: «Wszelka władza na świecie ustanowiona jest przez Boga i naszym obowiązkiem jest poddawać się tej władzy» (Rzym. 13,1)”40.

Wezwanie kontrastowało z ogólnospołecznym wyobrażeniem misji Kościoła. Autorytet duchownego Gieorgija - wyraziciela interesów robotników, ,proroka, którego wyczekiwali, aby wyprowadził ich z niewoli społecznej i gospodarczej" ${ }^{41}$ pozostawał w sprzeczności z pozycją hierarchów, przedstawicieli interesów samodzierżawnej władzy państwowej. Świątobliwy Synod był powszechnie traktowany jako carskie zgromadzenie biurokratyczne, a jego członów uważano za zwykłych urzędników, posłusznie wypełniających wolę imperatora. Pojawiły się nawet pogłoski, że nowym patriarchą zostanie Mikołaj II.

\footnotetext{
38 T. Crowdy, Historia szpiegostwa i agentury, przeł. J. Mikołajczyk, Warszawa 2010, s. 317-318; L. Bazylow, Historia Rosji, Historia Rosji, Wrocław, Warszawa, Kraków, Gdańsk 1975, s. 427-428; M. Smoleń, Podwójna gra Azefa. Z dziejów prowokacji carskiej ochrany, Kraków 1991, s. 107-113; Э. А. Хлысталов, Правда о священнике Гапоне, „Слово”, 2002, № 4, с. 102-111; В. Г. Джанибекян, Гапон. Революиионер в рясе, Москва 2006; Илия (Соловьёв), Дело Георгия Гапона, „Церковь и время", 2005, № 2, с. 199-211; С. А Нефёдов, Истоки 1905 года. „Революиия извне”?, „Вопросы истории”, 2008, № 1, с. 51-58; А. П. Корелин, И. М. Пушкарева, Н. Г. Королёва, С. В. Тюмюкин, И. А. Христофоров, Первая революуия в России. Взгляд через столетие, Москва 2005, с. 154-166.

39 J. Pajewski, op. cit., s. 247-248.

40 По поводу беспорядков робочих, „Церковный вестник”, 1905, № 3, c. $85-87$.

41 Д. В. Каннингем, op. cit., с. 92.
}

Hierarchowie w dosyć ostrej formie wypowiadali się przeciwko tym insynuacjom, co - zdaniem niektórych badaczy - legło u podstaw niechęci imperatora wobec wyższego duchowieństwa ${ }^{42}$.

Czynniki polityczne i społeczne, naciski rewolucyjne i wypływające nową falą demonstracje złożyły się na diametralną zmianę kursu religijnego dworu carskiego ${ }^{43} .31$ marca 1905 roku na posiedzeniu Świątobliwego Synodu Pobiedonoscew zaznajomił zebranych z oficjalnym stanowiskiem cara w sprawie otwarcia sesji soborowej:

„Realizacja w dzisiejszych, trudnych czasach tak wielkiego przedsięwzięcia, jakim byłoby zwołanie soboru, nie jest możliwa. Krok ten wymaga spokoju i rozmysłu. Pozostawiam Sobie (sic!), kiedy nadejdą lepsze ku temu czasy, nadzieję wsparcia, wzorem dawnych imperatorów, tego wielkiego dzieła - zwołania Wszechrosyjskiego Soboru Lokalnego celem kanoniczego rozpatrzenia spraw wiary i administracji cerkiewnej”"44.

Orzeczenie carskie zamykało duchowieństwu drogę do dalszych prac nad reformami, formalnie negując ideę zwołania ogólnorosyjskiego soboru. Członkowie zgromadzenia synodalnego, w wyczekiwaniu owego niedookreślonego momentu „kiedy nadejdą lepsze ku temu czasy”, zarzucili aktywność na polu reorganizacji wewnątrzcerkiewnej. Oddolnego ruchu reformatorskiego, rodzącego się we wspólnocie, nie można było jednak zatrzymać carskimi nakazami. Wiosna 1905 roku przyniosła znaczne ożywienie społeczności prawosławnej inteligencji. Jedynie na przełomie marca i kwietnia, na łamach prasy religijnej pojawiło się aż czterysta siedemnaście artykułów poruszających kwestie kierunku przyszłych zmian w Kościele prawosławnym. Praktycznie codziennie w opiniotwórczych czasopismach Nowoje Wriemija, Moskowskij Wiestnik czy Cerkownyj Wiestnik publikowano nowe materiały ${ }^{45}$. Zaczęto organizować związki o charakterze religijno-filozoficznym $^{46}$. W połowie listopada 1905 roku powołano Komitet Stronników Oświecenia Religijnego oraz Chrześcijańskie Bractwo Walki, którego członkami zostali Paweł Fłoreński Władimir Ern, Walentin Swiencicki i Aleksandr Jelczaninow $^{47}$. Wśród działaczy Petersburskiego Związku Religijno-Filozoficznego wymienić należy Antona Kartaszowa,

42 С. Нулис, На берегу Божьей реки, Москва 1992, ч. 2, с. 145-147; Н. Д. Жевахов, Воспоминания товарищза обер-прокурора Св. Синода князя Н. Д. Жевахова, Москва 1993, т. 2, с. 270; М. В. Зызыкин, Царская власть в России, Москва 2004, с. 590; С. Л. Фирсов, Русская Церковь накануне перемен (конец 1890-х - 1918 г2)..., с. 61-64.

43 С. С. Ольденбург, Царствование Императора Николая II, СанктПетербург 1991, с. 275-276.

44 Суt. za: И. В. Преображенский, оp. cit., с. 228.

45 С. Л. Фирсов, Русская Церковь накануне перемен (конеи 1890-х 1918 22)..., с. 322 ; М. А. Бабкин, ор. cit., с. 84.

46 Георгий (Флоровский), op. cit., с. 484-498; W. Krzemień, Filozofia $w$ cieniu prawosławia. Rosyjscy myśliciele religijni przełomu XIX $i$ XX wieku, Warszawa 1979, s. 15-16.

47 В. Свенцицкий, Собрание сочинений, Москва 2010, т. 2, с. 40-64, 584-594; Д. Головушкин, Нужна ли России христианская политическая партия? Из истории проблемы, „Гражданин”, 2003, № 3 , c. 51-52. 
Mikołaja Bierdiajewa, Wasilija Rozanowa, Dymitra Mierieżkowskiego oraz Sergiusza Bułgakowa ${ }^{48}$. Swoistym wydarzeniem było pojawienie się tygodnika Wiek, na łamach którego toczyły się dyskusje między petersburską inteligencją a duchowieństwem stolicy. Z Wiekiem współpracowali wybitni filozofowie, historycy i teologowie rosyjscy ${ }^{49}$.

Społeczno-polityczna myśl przewodnia ówczesnych publikacji o charakterze religijnym oscylowała wokół niezwłocznego zapewnienia Rosyjskiej Cerkwi Prawosławnej pełnej swobody samostanowienia. Oczekiwano jej zarówno w sferze decydowania o wspólnocie, jak też w wolności słowa, druku i ogólnospołecznym udziale prawosławnych w życiu Kościoła ${ }^{50}$. Autorzy artykułów prasowych wskazywali na zależność między sukcesem reform kościelnych a złagodzeniem ogólnego kursu polityki państwowej. Paralelność ich wywodów przyjęła kształt jednorodnych oczekiwań. Odrzucenie absolutyzmu państwowego miało stać się asumptem do zniesienia wszechwładzy hierarchów prawosławnych. Nadanie społeczeństwu prawa głosu w sprawach państwowych, w tym powołanie reprezentacji społecznej w formie Dumy, miało wpłynąć na udział osób świeckich w kościelnych organach decyzyjnych. Usunięcie $\mathrm{z}$ naczelnych organów władzy carskich urzędników, głównie oberprokuratora, winno doprowadzić do zmian personalnych w składzie Świątobliwego Synodu ${ }^{51}$.

Żądania wprowadzenia radykalnej reformy systemu synodalnego, wysuwane przez środowisko inteligencji prawosławnej, pobudziły aktywność Pobiedonoscewa. W sytuacji ogólnospołecznego nacisku, w czerwcu 1905 roku, podjęto wstępne kroki służące załagodzeniu prawosławnych nastrojów reformatorskich i stworzeniu iluzji zainteresowania ze strony władzy państwowej. Wyższe duchowieństwo cerkiewne otrzymało do wypełnienia specjalne formularze - ankiety z zapytaniami odnośnie do kierunku proponowanych reform, treści i zakresu sugerowanych zmian ${ }^{52}$.

\footnotetext{
48 О. А. Коростелев, О. Т. Ермишин, Религиозно-философское обиество в Санкт-Петербурге (Петрограде). Вехи истории, тематика заседаний, дискуссии, [в:] Религиозно-философское общество в Санкт-Петербурге (Петрограде). История в материалах и документах 1907-1917, ред. Т. М. Горяева, Москва 2009, т. 1, с. 5-26.

49 В. А. Фёдоров, Русская Православная Церковь и государство. Синодальный период 1700 - 1917 ге., Москва 2003, с. 266-267; Георгий (Ореханов), На пути к собору. Церковные реформы и первая русская револючия..., с. 121; М. А. Колеров, Не мир, но меч. Русская религиозно-философская печать от «Проблем идеализма» до «Вех» 1902-1909, Санкт-Петербург 1996, т. 1, с. 243.

50 С. С. Бычков, op. cit., с. 59-77.

51 Георгий (Ореханов), На пути к собору. Церковные реформы и первая русская револючия..., с. 80-89.

52 M. Muszyński, Władza kościelna $w$ prawosławiu rosyjskim wedtug Soboru Lokalnego 1917 - 1918 r., Warszawa 2006 [maszynopis: Uniwersytet Kardynała Stefana Wyszyńskiego], s. 139-140; Omзывьв епархиальных архиереев по вопросу о иерковной реформе в трёх ча-
}

W odpowiedziach biskupów, nadesłanych Świątobliwemu Synodowi, przeważała krytyka funkcjonowania w Cerkwi rosyjskiej niekanonicznych struktur synodalnych. Dążenie hierarchów do powrotu czysto chrześcijańskich źródeł zarządu Kościołem oznaczało rewizję rozwiązań epoki piotrowej. Władza rewizyjna - ustawodawcza i wykonawcza - należeć winna, w ich zgodnej opinii, do zgromadzenia soborowego ${ }^{53}$. Dominujące, niemalże jednogłośne przekonanie hierarchów o konieczności zmian wyższej administracji cerkiewnej, nieuniknione do rozpatrzenia kwestie dookreślenia stosunku wobec władzy państwowej, wytyczenia kierunku reform Świątobliwego Synodu i zakreślenia zmian kompetencyjnym urzędu oberprokuratorskiego, z jednoczesnym podniesieniem przez respondentów idei restytucji patriarchatu, miały charakter teoretyczny, a ich treśc przybrała formę precedensu. Kuriozum sytuacji Rosyjskiej Cerkwi Prawosławnej w początkach XX wieku polegało, ogólnie rzecz ujmując, na wytworzeniu w środowisku cerkiewnym iluzji władzy ustawodawczej należącej do suwerena - społeczeństwa, podczas gdy jedynie zgoda rosyjskiego cara była warunkiem niezbędnym i koniecznym dla praktycznej realizacji cerkiewnych postulatów reformatorskich.

Skostniałość funkcjonującego systemu władzy państwowej i konserwatyzm najbliższych współpracowników cara, głównie oberprokuratora Pobiedonoscewa, przez kolejną dekadę XX wieku stał się hamulcem postulowanych w prasie, na ulicach, na katedrach arcybiskupich i uniwersyteckich oraz w ławach Świątobliwego Synodu głębokich reform strukturalnych, kanonicznie ustanawianych i wprowadzanych w duchu soborowości. Problem kształtu wewnętrznego Rosyjskiej Cerkwi Prawosławnej powrócił na forum ogólnocerkiewne dopiero dziesięć lat później na posiedzeniach roboczych Soboru Lokalnego Rosyjskiej Cerkwi Prawosławnej ${ }^{54}$.

стях, Санкт-Петербург 1906; С. Л. Фирсов, Русская Церковь накануне перемен (конец 1890-х - 1918 г2)..., с. 193; Николай (Балашов), На пути к литургическому возрождению, Москва 2001, с. 24-30; Д. А. Головушкин, Феномен обновленчества в русском православии первой половины ХХ века..., с. 41-52; С. С. Бычков, ор. cit., с. 97-113.

53 Георгий (Ореханов), На пути к собору. Церковные реформы и первая русская револючия..., с. 135-136; Государственный архив Российской Федерации, Арсений (Авксентий Георгиевич Стадниикий), митрополит новгородский и старорусский, Свод отзывов епархиального духовенства на миссионерскую деятельность среди раскольников и сектантов в свете производимой государством политики веротерпимости, отзывы о преобразовании иерковного управления в России и мнения епархиального духовенства о порядке приобретения и отчуждения иерковной собственности, ф. 550, оп. 1, д. 196, л. 13-16.

54 O Soborze zob. szerzej: K. Pawełczyk-Dura, Rosyjskie prawosławie w okresie wczesnosowieckim (1917-1927), Lublin 2014, s. 65-81. 


\section{Bibliografia}

\section{Archiwa}

Российский государственный исторический архив, Яцкевич Виктор Иванович (1861-1924), Директор Канцелярии обер-прокурора Синода, ф. 1579, оп. 1, д. 36

Государственный архив Российской Федерации, Арсений (Авксентий Георгиевич Стадницкий), митрополит новгородский и старорусский, Свод отзывов епархиального духовенства на миссионерскую деятельность среди раскольников и сектантов в свете производимой государством политики веротерпимости, отзывы о преобразовании церковного управления в России и мнения епархиального духовенства о порядке приобретения и отчуждения церковной собственности, ф. 550, оп. 1, д. 196

\section{Czasopisma}

„Богословский сборник Православного Свято-Тихоновского богословского института": 1999 (№ 2), 1999 (№ 4)

„Вестник Московского университета. Серия 8: История”: 1999 (№ 4)

„Вестник русского христианского движения”: 1993 (№ 168)

„Вопросы истории”: 2008 (№ 1)

„Гражданин”: 2003 (№ 3)

„Журнал Московской Патриархии”: 2000 (№ 12), 2001 (№ 11)

„Красный архив”: 1926, т. 5 (№ 18), 1928, т. 5 (№ 30)

„Московские Епархиальные Ведомости”: 2011 (№ 7/8)

„Новое время”: 1905 (№ 10)

„Православная община”: 1996 (№ 3), 1998 (№ 5)

„Прибавления к Церковным ведомостям”: 1905 (№ 45)

„Просветитель”: 1994 (№ 1)

„Религии мира. История и современность”: 1983 (№ 37)

„Русское прошлое”: 1996 (№7)

„Слово”: 1905 (№ 108), 2002 (№ 4)

„Церковный вестник”: 1905 (№ 3), 1905 (№ 11)

„Церковь и время”: 2000 (№ 3), 2005 (№ 2)

\section{Opracowania}

Bazylow L., Historia Rosji, Historia Rosji, Wrocław, Warszawa, Kraków, Gdańsk 1975

Bazylow L., Ostatnie lata Rosji carskiej. Rzady Stołypina, Warszawa 2008

Bogolepov A. A., Church Reforms in Russia 1905-1918, Bridgeport 1966

Cierniak U., Literacki wymiar kultury religijnej staroobrzędowców, Częstochowa 1997

Crowdy T., Historia szpiegostwa $i$ agentury, przeł. J. Mikołajczyk, Warszawa 2010

Heller M., Historia Imperium Rosyjskiego, przeł. E. Melech, T. Kaczmarek, Warszawa 2002

Krzemień W., Filozofia w cieniu prawostawia. Rosyjscy myśliciele religijni przełomu XIX i XX wieku, Warszawa 1979

Marples D., Historia ZSRR od rewolucji do rozpadu, przeł. I. Scharoch, Wrocław 2006

Maszkiewicz M., Mistyka i rewolucja. Aleksander Wwiedeński i jego koncepcja roli cerkwi w państwie komunistycznym, Kraków 1995
Miasto i kultura ludowa $w$ dziejach Białorusi, Litwy, Polski i Ukrainy, red. J. Wyrozumski, Kraków 1966

Muszyński M., Władza kościelna $w$ prawosławiu rosyjskim wedtug Soboru Lokalnego 1917 - 1918 r., Warszawa 2006 [maszynopis: Uniwersytet Kardynała Stefana Wyszyńskiego]

Pajewski J., Historia powszechna 1871-1918, Warszawa 1998

Panorama myśli kontrrewolucyjnej, red. J. Goćkowski, J. Bartyzel, M. Bohun, A. Woźniak, Pułtusk 2007

Pawełczyk-Dura K., Rosyjskie prawosławie $w$ okresie wczesnosowieckim (1917-1927), Lublin 2014

Pipes R., Rewolucja rosyjska, przekł. T. Szafar, Warszawa 2006

Prawosławie, red. J. Drabina, Kraków 1996

Przybył E., W cieniu Antychrysta: idee staroobrzędowców w XVII w., Kraków 1999

Smoleń M., Podwójna gra Azefa. Z dziejów prowokacji carskiej ochrany, Kraków 1991

Sobczak J., Mikołaj II - ostatni car Rosji, Warszawa 2009

Stawiński P., Sekty, schizmy i herezje w Rosji. Stownik, Kraków 2000

Williams B., Lenin, przeł. A. Tuszyńska, Wrocław 2002

Żywot protopopa Awwakuma przez niego samego nakreślony $i$ wybór innych pism, red. W. Jakubowski, Wrocław-Gdańsk 1972

Бабкин М. А., Священство и Царство. Россия начало ХХ века - 1918 г. Исследования и материаль, Москва 2011

Бычков С. С., Русская Церковь и императорская власть. Очерки по истории Православной Российской церкви 1900-1917 г2., Москва 1998, т. 1

Витте С. Ю., Воспоминания, Москва 1960, т. 1, 2

Владислав (Цыпин), История Русской Церкви 1917-1997, Москва 1997

Георгий (Ореханов), На пути к собору. Церковные реформы и первая русская революччия, Москва 2002

Георгий (Флоровский), Пути русского богословия, Париж 1983

Головушкин Д. А., Феномен обновленчества в русском православии первой половины ХХ века, Санкт-Петербург 2009

Данилушкин М. Б., Никольская Т. К., Шкаровский М. В., Дмитриев В. П., Кутузов Б. П., История Русской Православной Церкви. От восстановления патриаршества до наших дней 1917-1970 г2., Санкт-Петербург 1997, т. 1

Джанибекян В. Г., Гапон. Револючионер в рясе, Москва 2006

Ежегодная богословская конференция Православного Свято-Тихоновского Богословского Института. Материалье, ред. В. Н. Воробьёв, Москва 1996

Жевахов Н. Д., Воспоминания товарища обер-прокурора Св. Синода князя Н. Д. Жевахова, Москва 1993, т. 2

Зеньковский С., Русское старообрядчество: Духовные движения ХVII века, Москва 1995

Зызыкин М. В., Царская власть в России, Москва 2004

Иакинф (Дестивель), Поместный Собор Российской Православной Церкви 1917-1918 г2. и принщип соборности, Москва 2008 
К. П. Победоносиев: pro et contra. Личность, общественно-политическая деятельность и мировоззрение Константина Победоносиева в оченке русских мыслителей и исследователей. Антология, ред. Д. К. Бурлака, Санкт-Петербург 1996

Каннингем Д. В., С надеждой на собор. Русское религиозное пробуждение начала века, Лондон 1990

Колеров М. А., Не мир, но меч. Русская религиозно-философская печать от «Проблем идеализма» до «Вех» 19021909, Санкт-Петербург 1996, т. 1

Корелин А. П., Пушкарева И. М., Королёва Н. Г., Тюмюкин С. В., Христофоров И. А., Первая революуия в России. Взгляд через столетие, Москва 2005

Лавров В. М., Лобанов В. В., Лобанова И. В., Мазырин А. В., Иерархия Русской Православной иеркви, патриаршество и государство в революиионную эпоху, Москва 2008

Миловидов В., Старообрядчество в прошлом и настоящем, Москва 1969

Николай (Балашов), На пути к литургическому возрождению, Москва 2001

Нулис С., На берегу Божьей реки, Москва 1992, ч. 2
Ольденбург С. С., Царствование Императора Николая II, Санкт-Петербург 1991

Отзывы епархиальных архиереев по вопросу о иерковной реформе в трёх частях, Санкт-Петербург 1906

Письма Победоносиева к Александру III, Москва 1926, т. 2

Победоносцев К. П., Московский сборник. Церковь и государство, Москва 1896

Поспеловский Д. В., Русская Православная Церковь в ХХ в., Москва 1995

Преображенский И. В., Сборник статей духовной и светской периодической печати по вопросу о реформе, Санкт-Петербург 1905

Религиозно-философское общество в Санкт-Петербурге (Петрограде). История в материалах и документах 1907-1917, ред. Т. М. Горяева, Москва 2009, т. 1

Свенцицкий В., Собрание сочинений, Москва 2010, т. 2

Современники о патриархе Тихоне, сост. М. Е. Губонин, Москва 2007, т. 2

Фёдоров В. А., Русская Православная Церковь и государство. Синодальный период 1700 - 1917 гг., Москва 2003

Фирсов С. Л., Русская Церковь накануне перемен (конеи 1890-x - 1918 г2), Москва 2002

Rozmiar artykułu: 0,8 arkusza wydawniczego 


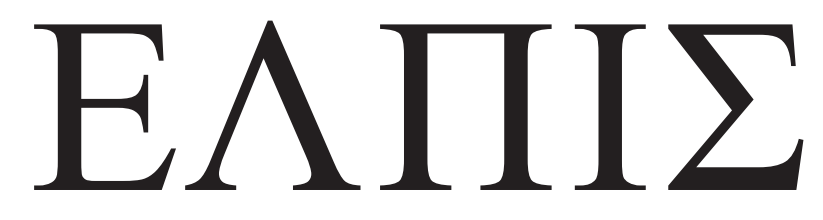

CZASOPISMO TEOLOGICZNE KATEDRY TEOLOGII PRAWOSŁAWNEJ UNIWERSYTETU W BIAŁYMSTOKU

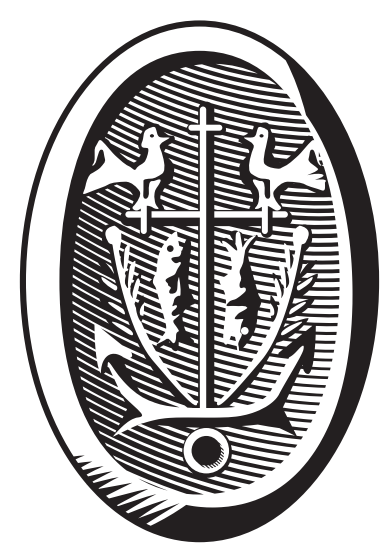

ADRES REDAKCJI

ul. Ludwika Zamenhofa 15, 15-435 Białystok, Polska tel. 85 745-77-80, e-mail: elpis@uwb.edu.pl www.elpis.uwb.edu.pl 